\title{
Loss of Sagebrush Ecosystems and Declining Bird Populations in the Intermountain West: Priority Research Issues and Information Needs
}

\begin{abstract}
Sagebrush lands in the Intermountain West are declining rapidly in quality and extent. Consequently, populations of many bird species dependent on these ecosystems also are declining. The greater sage-grouse has been petitioned for listing as a threatened and endangered species, and other species of sagebrush-obligate birds have special conservation status in most states. We identified the primary issues and information needs during a multi-agency workshop, conducted in response to concerns by management agencies related to declining bird population trends in sagebrush habitats. Priority needs were to (1) obtain a better understanding of bird response to habitat and landscape features, (2) develop monitoring designs to sample habitats and bird populations, (3) determine the effects of land use on sagebrush habitats and dependent bird species, and (4) identify linkages between breeding and wintering ranges. This agenda will identify causes and mechanisms of population declines in birds dependent on sagebrush ecosystems and will lead to better management of the ecosystems upon which they depend.
\end{abstract}

\section{Decline of Birds in Sagebrush Landscapes}

Birds breeding in sagebrush landscapes in the Intermountain West have been faced with radical and rapid changes in their habitats. Sagebrush habitats are among the nation's most imperiled ecosystems, and very little remains in undisturbed condition in the Great Basin and Columbia Plateau ecoregions (Map 1). Disturbance, land use practices, and invasion by exotic vegetation have altered the composition of sagebrush communities or led to extensive fragmentation and loss. As such, the form and function of these habitats may be changed forever across large areas.

Populations of shrubland and grassland birds have had the greatest rate of declines of any group of birds, and many species receive special conservation status. Populations of greater sage-grouse (Centrocercus urophasianus) have declined by $33 \%$ from their long-term average population size and have been lost from much of their historical range. The extent of declines for most other species is unknown because they are not adequately sampled by existing surveys. In addition, the way in which habitat changes influence populations of most species is unknown because we know little about their basic life histories.

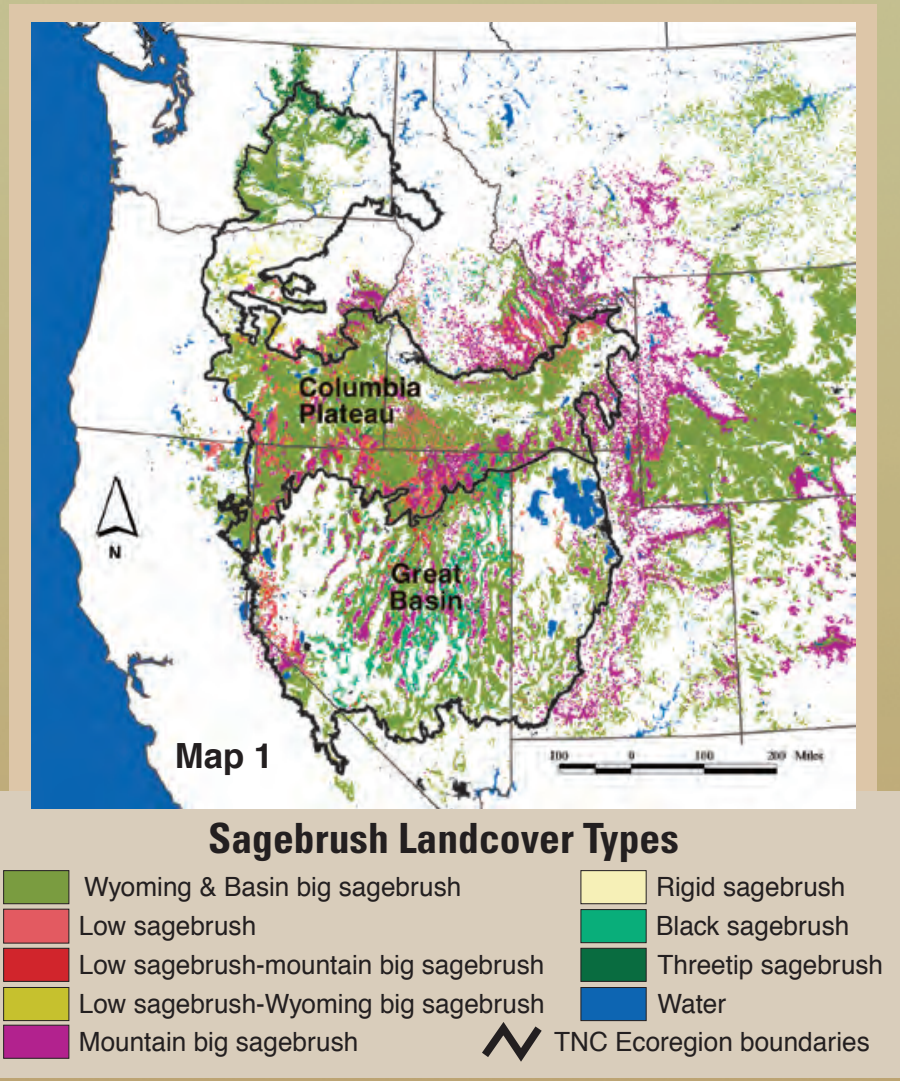

Public agencies are largely responsible for the issues associated with sagebrush habitats and associated bird populations. Greater than $75 \%$ of the sagebrush lands, which cover approximately $58.4 \times 10^{6}$ ha (144 million acres or about the size of the state of Texas) in the Great Basin and Columbia Plateau, are under public ownership; the U.S. Bureau of Land Management has the largest area under management authority. Given this perspective, the petitions to list the greater sagegrouse as a Threatened and Endangered Species carry significant implications for land management over a large portion of the Intermountain West.

\section{Priority Research Issues and Information Needs}

At a multi-agency workshop, scientists and managers identified the priority research issues and information needed to manage sagebrush habitats and dependent bird species. Participants included representatives of the U.S. Geological Survey (USGS), U.S. Fish and Wildlife Service, U.S. Bureau of Land Management, U.S. National Park Service, 
U.S. Department of Energy,

U.S. Department of Defense,

U.S. Forest Service, state wildlife agencies (Idaho,

Nevada, Utah, and Washington), the University of California Riverside, Boise State University, University of Montana, Michigan State University, Oregon State University, University of Nevada, Albertson College of Idaho,

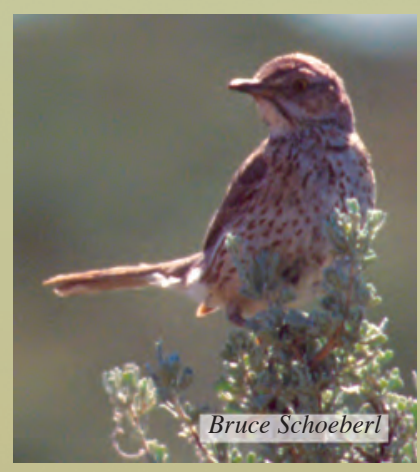

sage thrasher
Idaho State University, the Center for Conservation Research, Audubon Society, The Nature Conservancy, the High Desert Ecological Research Institute, Partners in Flight, Point Reyes Bird Observatory, Idaho Bird Observatory, Stoller Corporation, and the Idaho Power Company. The different missions of the agencies and individuals involved at the workshop reflected varying needs and applications of information but with a common need for improved information about birds associated with sagebrush habitats.

\section{Bird Response to Habitat and Landscape Features}

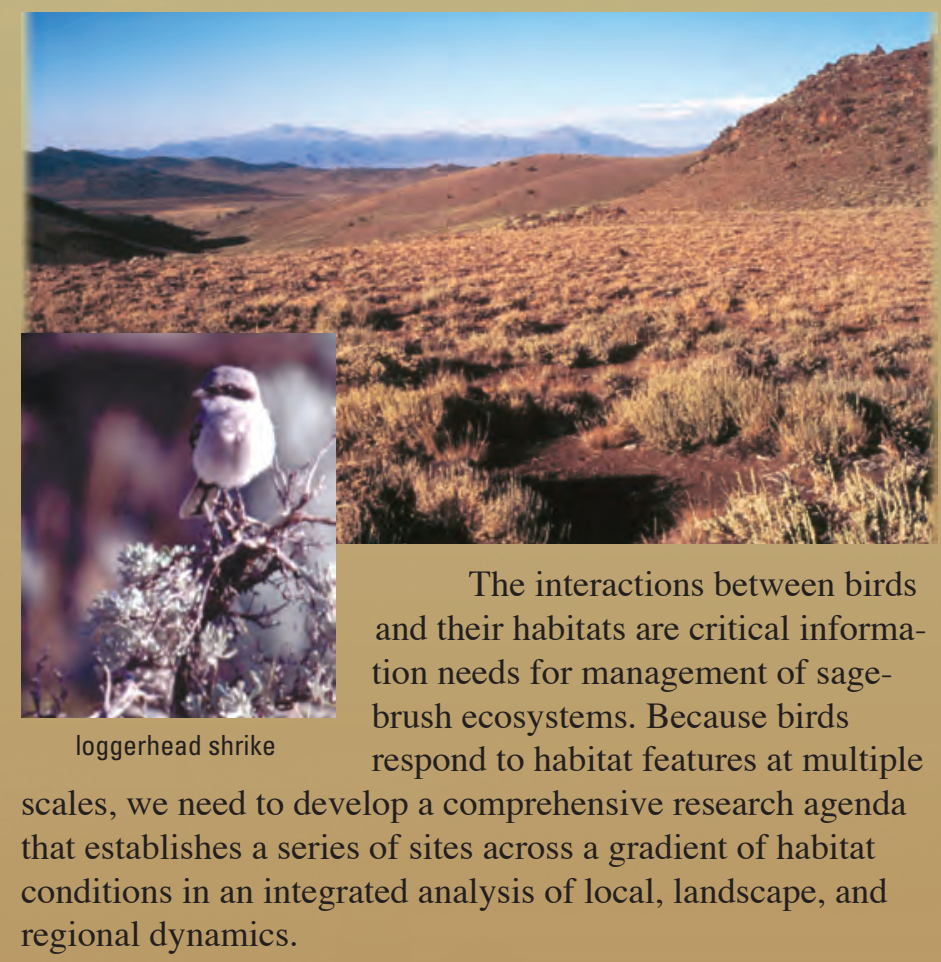

\section{Monitoring and Survey Designs}

We need to assess local and range-wide status of population trends of birds dependent on sagebrush ecosystems. Many species are not adequately sampled by existing programs such as the Christmas Bird Count or the USGS Breeding Bird Survey. Therefore, few data exist on distribution and abundance for many species of birds living in sagebrush habitats on either breeding or wintering ranges. We first need to determine how well existing surveys sample habitats and birds. We then need to develop monitoring techniques and a protocol to incorporate local surveys into a broad program for regional assessments.

\section{Effects of Land Use Practices}

Most of the sagebrush lands in the Great Basin and Columbia Plateau have been changed by land use such as livestock grazing, agriculture, or resource extraction. These uses can influence habitats either directly or indirectly, alter the disturbance regime (such as change the frequency of fire), and impact bird communities. Restoration of sagebrush habitats is a major management challenge. We need to better understand the impact of management and land use activities on the form and function of sagebrush habitats and the consequences for bird communities. Although these activities significantly impact sagebrush habitats, they also are under the management authority of public agencies.

\section{Wintering Ground and Migration}

We know little about birds once they leave their breeding grounds in the Great Basin and Columbia Plateau for wintering ranges in the southwestern United States and northern Mexico. We need to develop technologies to mark

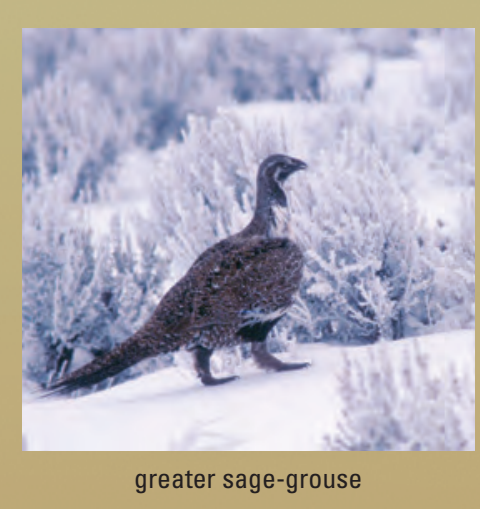

\section{Conclusion}

This agenda of priority research issues and information needs is large in scope, and will require multiple years of funding as well as participation by numerous agencies, universities, and non-governmental entities. Ultimately, this approach will develop the management solutions that benefit sagebrush habitats and their dependent bird and track birds. We also need to design better methods to determine the spatial and temporal distribution of birds during nonbreeding periods. The linkage between breeding and wintering grounds is critical to understanding the regional dynamics and temporal periods that impact bird populations breeding in sagebrush ecosystems. species in the Intermountain West, species which are a unique and valuable component of regional and global biological diversity.

\section{Contacts:}

Steven T. Knick, USGS Forest and Rangeland

Ecosystem Science Center, Snake River Field Station, 970 Lusk Street, Boise, ID 83706 (ph: 208-426-5208; email: steve_knick@usgs.gov)

Charles Van Riper, III, USGS Southwest Science Center, Northern Arizona University, PO Box 5614, Bldg. 24, Flagstaff, AZ 86001 (ph: 928-556-7466; email: charles_van_riper@usgs.gov) 